\section{Reviewing Optimized Portfolios: All Seasons Strategy}

Raúl D. Navas ${ }^{1}$

Sónia R. Bentes ${ }^{2}$

\section{Abstract}

Purpose - Our research revisits the study "Optimized Portfolios: All Seasons Strategy," where we support diversified portfolios to minimize risk, considering the principle of Markowitz.

Theoretical framework - We re-examine the results of Navas et al. (2020). The idea behind this is the theory of Harry Markowitz (1959, 2010), regarded as the founder of modern portfolio theory.

Design/methodology/approach - Six different models are run using data from 2000 to 2010 and a solver is developed, where the GRG Nonlinear engine for linear solver problems is the solving process chosen.

Findings - The GRG Nonlinear engine is efficient if we take into account ways to lower volatility since it is inversely correlated to predictions.

Practical \& social implications of research - To predict the composition of the portfolios, we do not take into consideration the crash of gold and precious metals in 2013.

Originality/value - Robust portfolios can be generated where the risk is minimized and the return is maximized.

Keywords - MPT, Markowitz, portfolio formation, Sharpe ratio, volatility.

1. Instituto Politécnico de Lisboa - ISCAL, Lisboa, Portugal and NECE - Research Center in Business Sciences (NECE-UBI), Covilhã, Portugal

2. Instituto Politécnico de Lisboa - ISCAL, Lisboa, Portugal, Business Research Unit - Instituto Universitário de Lisboa (BRU-IUL), Lisbon, Portugal

How to cite:

Navas, R. D., Bentes, S. R. (2021). Reviewing Optimized Portfolios: All Seasons

Strategy. Revista Brasileira de Gestão de Negócios, 23(4), p.696-713.
Received on:

11/05/2020

Approved on:

03/22/2021

Responsible Editor:

Prof. Dr. Jose Ruiz

\section{Evaluation process:}

Double Blind Review

\section{Reviewers:}

Adriana Bruscato Bortoluzzo; Viviana Fernandez.

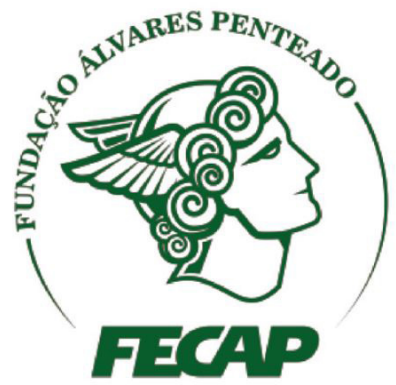

Revista Brasileira de Gestáo de Negócios

https://doi.org/10.7819/rbgn.v23i4.4134 


\section{Introduction}

Conventional knowledge and traditional portfolio management present us with a model that continues to indicate that it cannot survive when times are tough. So, we explore whether we can design portfolios - distributions of assets - that might perform well in an economic setting in the future resembling those of 2008 or even the pandemic in 2020, since no one knows what will happen in one, two, or five years' time.

We explore this issue by re-examining the results of Navas, Bentes, and Navas (2020), who conducted one of the most prominent studies in the literature. In the last paragraph, Navas proposed six different models that seek to optimize returns but reduce risk at the same time. The idea behind this is the theory of Markowitz (1959, 2010), regarded as the founder of modern portfolio theory. It illustrates and synthesizes the basic idea behind the work that won Markowitz the Nobel Prize: portfolio investments should not be seen individually, but as a collective. There is a trade-off between risk and return, so how investments behave together and how they are diversified will determine return (Robbins, 2014).

We try to change two aspects of the last paper from Navas, namely: i) we make minor changes to the list of assets, including more affordable assets and ones that are easier to obtain from retail investors. For example, one of the limitations of the study was the fact that the VIX (the metric used to measure volatility) is not well reflected in ETFs (exchange-traded funds), which are more based on the short term or medium term, unlike the standard VIX. These have worked as a "short" rather than as a volatility index. The EUR/USD exchange rate has been removed too since it does not have an influence on the portfolios. So we work with three only classes of assets: equities, bonds, and commodities (especially metals); ii) Navas used two decades' of data to feed the solver (2000-2018) and we intend to use only the first decade (2000-2010) and "predict" the second one (2011-2020), by watching annual returns and volatility. The goal here is to check if these are predictable, using a variety of assets for the portfolio. Because we do not want to contradict the EMH (Efficient Market Hypothesis), a variety of assets are used to form portfolios, some not correlated with each other, and not a single asset.

We mix a wide range of stocks (mainly from different countries and key industries as well), various types of bonds (US, EUR, Emerging Markets, and
German Treasury and Corporate Bonds), and a number of commodities via a solver for linear solver problems using the GRG (Generalized Reduced Gradient) Nonlinear engine. The range of data that will serve for our prediction is from 2000 to 2010 with the goal of capturing two market collapses (the 2002 technology crisis and the 2008 financial crisis) and a strong decade ahead (except the pandemic year of 2020). Our predictions will be for the 2011-2020 period. Our main research question is: is it possible to build a portfolio or a bunch of portfolios that produce robust results in a poor decade but, at the same time, also in a good decade? The results indicate that it is certainly feasible if the construction of the portfolios takes into account lowering volatility. We found a negative correlation between volatility and predictions, meaning that the lower the volatility found in the portfolio, the more robust the predictions will be.

Section 2, the literature review, discusses the philosophy behind the idea of this study and the empirical accomplishments of various authors. Section 3 introduces six different models where the solver is used. Section 4 provides a preliminary analysis of the data collected. Section 5 presents the effects of the models and suggests several portfolios to be used. Section 6 concludes the paper.

\section{Literature Review}

In the turbulent modern-day context, the instability of economic markets is relevant because it influences the day-to-day lives of corporations and individuals. This is more obvious during times of recession such as of the one witnessed in 2008, which was in large part due to a loss of solidity within the worldwide economic system (Bentes, 2011).

Whatever the perspective, one fact is indisputable: instability is increasingly frequent in the markets. Several reasons for this have been pointed out. The first, and simplest of all, relates to high levels of risk and uncertainty. The second is the growing complexity of the market, where increasingly sophisticated products have emerged, fundamentally based on the development of the derivatives market (Bentes, 2011).

In addition to this, there is also the effect of globalization, which increases price variations in various financial markets, depending on their degree of integration. For all these reasons, it is important to analyze and model the volatility of the returns on financial assets traded on stock markets, since only in this way will investors have 
the tools needed for their decision making (Bentes, 2011; Robbins, 2014; Soros, 2008).

Many capitalists are naive in their financial beliefs and do not understand basic ideas concerning equity or diversification (Hirshleifer, 2015; Lusardi \& Mitchell, 2011). Graham (1949, as cited in Graham et al., 2003), the father of value investing, proposed that a balanced portfolio should be $50 \%$ equity and $50 \%$ bonds, and that an intelligent investor may, under certain conditions, own $100 \%$ equity in their portfolio, only if they had a positive return in the event of a crisis. By dividing their assets between $50 \%$ stocks and $50 \%$ bonds (or some similar variation), several investors would think they had diversified and reduced their risk. However, after Markowitz (1959) completed his work on efficient portfolios, he concluded that what investors are doing is taking more risks than they think. This is because, in line with Dalio, as cited in Markowitz (1959, 2010) and Robbins (2014), shares are three times riskier (i.e., volatile) than bonds. In fact, a 50/50 portfolio gives us more like a 95\% risk distribution in stocks. At first glance, having $50 \%$ of the money in shares seems to be relatively balanced. But, as it turns out, the risk would be around 95\%, given the volatility of the stock composition. So, if the shares sink, the entire portfolio will sink. And the balance has been lost. How does this concept work in real life? From 1973 to 2013, the S\&P 500 lost nine times and accumulated losses totaling $134 \%$. During the same period, bonds (represented by the Barclays Aggregate Bond Index) lost money only three times and the accumulated losses were $6 \%$. Consequently, by having a 50/50 portfolio, losses would have increased by $95 \%$ (Navas et al., 2020).

According to Assaf (2009), portfolio risk is lower than the individual risk of assets because there is a correlation element that minimizes the risk, even when the correlation between the assets is very close to 1 . Thus, through diversification, using assets with a low correlation, if an asset performs poorly or even negatively, it will be offset by the good performance of the other assets (Markowitz, 1952, 1959, 2010; Navas et al., 2020; Robbins, 2014). Although the risk of a portfolio depends on the way its components relate to each other, it cannot be eliminated, only reduced, and one must take into account whether the costs to reduce the risk are worth it.

Silva, Carmona, and Lagioia (2011) analyzed whether there is a relationship between the risk of a portfolio that is considered sufficiently diversified in the Brazilian stock market, composed of companies classified in the IGC, in comparison to the market portfolio. Using the Markowitz model (1952), they sought to find the minimum variance portfolios, in order to test the hypothesis that there is a relationship between the risk of these portfolios that are considered sufficiently diversified. The results indicated that such portfolios, composed of IGC assets, are superior to the market portfolio. That is, through the theory of diversification, it is possible to obtain an inverse relationship between risk and good corporate governance practices. Additionally, the selected IGC portfolio from Silva et al. (2011) outperforms the IGC and IBOVESPA portfolio, respectively, using the coefficient of variation, that is, it has less risk contained in each additional return.

Sanvicente and Bellato (2004) carried out a study in which they sought to determine the number of shares needed for a portfolio to be sufficiently diversified in the Brazilian stock market, considering the transaction costs that exist in an imperfect capital market. This study was based on the idea that diversification should be applied while the marginal benefits (risk reduction) exceed the marginal costs (transaction costs). The authors concluded that the ideal scenario would be to engage in a little portfolio diversification, based on a diversification limit for the Brazilian capital market of six shares, due to the sensitivity of the number of shares to transaction costs.

Ang, Hodrick, Xing, and Zhang (2006, 2009) show that high future stock returns are generated by companies with more negative coefficients regarding changes in aggregate risk calculated by the Volatility Index (VIX). Other studies have examined how companies' vulnerability to various risk factors can be useful in the process of forecasting returns. The VIX is used because it is a good representation of the total economy's expected (systemic) risk (Mikosz, Macedo, \& Roma 2020).

It is in this context that the ARCH (q) model proposed by Engle (1982) appears, which attempts to model the conditioned heteroscedasticity shown by the profitability of financial assets.

Gabriel (2014), analyzed the market risk of an international investment portfolio using a new methodological proposal, based on Value-at-Risk (VaR). This author employed the covariance matrix of GARCHtype multivariate models and the theory of extreme values to see if an international diversification strategy minimizes market risk, as well as to verify if the VaR methodology adequately captures that same risk, by applying performance validation tests. Some authors who use variants of GARCH 
(GARCH, E-GARCH, T-GARCH, etc.) have shown that these models explain price variations and their volatility based on news (good or bad) and its impact and that they can be used for any type of asset (e.g.: Aboura \& Wagner, 2016; Bentes, Menezes, \& Ferreira 2013; Brailsford \& Faff, 1996; Navas, Bentes, \& Gama, 2018; Wu, Meng, \& Velazquez, 2015). Gabriel (2014) concludes that VaR is a feasible alternative to accommodate the high turbulence in the markets and can be considered as a valid tool in the risk management of investment portfolios.

EVT (Extreme Value Theory), based in statistics dealing with the extreme deviations from the median probability distribution, is another example of a model that can be effective in environments with high market volatility (e.g.: Assaf, 2009; Jesús-Gutiérrez \& SantillánSalgado, 2019; Marimoutou, Raggad, \& Trabelsi 2009; Mutu, Balogh, \& Moldovan, 2011; Zhao, Scarrott, Oxley, $\&$ Reale, 2010). Based on a given ordered sample of a given random variable, it seeks to assess the probability of occasions that might be more intense than any formerly observed.

Lameira, Ness, Quelhas, and Pereira (2013) confirmed, at the equity level and after the application of various econometric methods, the hypothesis that better sustainability practices are associated with better performance, higher values, and lower risks. In addition, sustainability is directly associated with value and through variables that mediate performance and risk. Finally, it was found that market value, the degree of operational leverage, the return on assets (ROA), and volatility are possible determinants of the quality of companies' sustainability practices (Lameira et al., 2013; Orlitzky, Schmidt, \& Rynes, 2003; Silva et al., 2011; Teixeira, Nossa, \& Funchal 2011).

According to Easley, Hvidkjaer, and O'Hara (2002) and Lambert, Leuz and Verrecchia (2007), based on theoretical models applied to equity, accruals represent a measure of informational risk. The risk of uncertainty caused by the size of accruals affects the cost of capital of companies and accruals quality is a priceable risk factor that plays a statistically and economically significant role in determining a company's cost of equity (Martins, Monte, \& Machado, 2019; Piotroski \& So, 2012; Piotroski, 2005, 2000; Richardson, Tuna, \& Wysocki, 2010; Sloan, 1996).

Also regarding stocks, according to Mikosz et al. (2020), there are a few authors that have built models that reduce risk significantly (e.g., the FO model from Feltham \& Ohlson, 1995, 1999) by incorporating dynamic expectations about the level of systemic risk in the economy. Stocks with a high negative covariance with changes in the aggregate risk of the economy should have higher average returns (Ang et al., 2009). Many authors also argue that the Capital Asset Pricing Model (CAPM) and the Fama and French 3-factor model (FF) have produced fewer forecasting deviations, when compared to many others (Fama, 1998, 1970; Mikosz et al., 2020).

Based on this theoretical background and the Modern Portfolio Theory (MPT) from Markowitz (1952, 1959), we present six different portfolios, aiming at a certain risk, to deliver the maximum return to the investor.

\section{Model Framework}

Six portfolio models are proposed: first, a solver is used where the Generalized Reduced Gradient (GRG) Nonlinear Engine for Linear Solver Problems is the chosen solution process. This type is as follows:

$\max f(x): h(x)=0, L \leq x \leq U$,

where $h$ has dimension $m$. The method can be partitioned into $x=(v, w)$ such that:

- $\quad v$ has dimension $m$ (and $w$ has dimension $n-m$ );

- $\quad$ the values of $v$ are strictly within the bounds: $L_{v}<v<U_{v}$ (this is a nondegeneracy assumption);

- $\quad \nabla_{v} h(x)$ is nonsingular at $x=(v, w)$.

As in the linear case, for any $w$ there is a unique value, $v(w)$, such that $h(v(w), w)=0$ (c.f., Implicit Function Theorem), which implies that $d v / d w=\left(\nabla_{v} h(x)\right)^{-1} \nabla_{w} h(x)$. The idea is to choose the direction of the independent variables to be the reduced gradient: $\nabla_{w}\left(f(x)-y^{T} h(x)\right)$, where $y=d v / d w=\left(\nabla_{v} h(x)\right)^{-1} \nabla_{w} h(x)$. Then, the step size is chosen, and a correction procedure applied to return to the surface, $h(x)=0$.

The key steps (with the exception of the correction procedure) are the same as the reduced gradient process, adjusting the working set as necessary.

The composition of portfolios is based on the solver and varies. The six portfolios have different risks and returns, depending on the profile of each investor. There are cautious portfolios and aggressive portfolios. The solver configuration of each portfolio is shown below.

As far as variable cells are concerned, the percentage of the weighting of the category of assets is variable. A broad range of stock indices, bonds, and commodities is used. The specifics of each family of assets used in the model are shown in the table below. In total, 32 assets are used: 
As far as the constraints are concerned, the sum of the percentage of each asset is equal to 1, i.e. $100 \%$ :

$$
\sum x \operatorname{Assets}(a)=1
$$

Where $x=$ coefficient; $a=$ each type of asset as showed in Table 1 - Asset list.

Note: It is forced to make unconstrained variables non-negative.

The period is set to between 2000 and 2010 and then we project results for the period between 2011 and 2020. The model uses past returns (monthly returns) for each asset and the portfolios are re-balanced monthly based on the optimal weighting of each asset. It is based on monthly returns, calculated as follows:

$$
R_{t}=\frac{P_{t}}{P_{t-1}}-1
$$

Where $R_{t}=$ monthly returns; $P_{t}$ and $P_{t-1}$ are the assets prices at moments $t$ and $t-1$, respectively.

Note: The cost of weighting the portfolio is ignored in this study, since each broker has their own commissions.

Lastly, for each model, the specification and objectives are presented as follows:

\section{I Model I: maximize Sharpe ratio}

The objective of this model is to maximize the Sharpe ratio (SR). The division is based on the average yearly return and the standard deviation, calculated as follows:

$$
S R=\frac{i}{\sigma}
$$

Where $S R=$ Sharpe ratio; $i=$ return; $\sigma=$ standard deviation.

\section{Set objective: SR}

To: Maximum

\subsection{Model 2: maximize rate of return}

In this model, the aim is to provide the maximum return to the investor, ignoring the volatility, so we can argue that Model 2 presents a higher risk compared to the others:

Set objective: Rate of return

To: Maximum

\subsection{Model 3: minimum variation}

This model minimizes variations in returns in order to reduce volatility:

\section{Set objective: Var}

To: Minimum

\subsection{Model 4: maximize rate and Sharpe ratio}

The concern in this model is to provide some extra return to the investor. It may generate more revenue

Table 1

\section{Asset list}

\begin{tabular}{lcc}
\hline Equities index & Bonds & Commodities \\
\hline SP 500 & US Treasury 20+y & All Commodities \\
Dow Jones 30 & US Treasury 7-10y & Physical Precious Metals \\
Nasdaq 100 & EUR Treasury 20+y & Gold \\
EUR Stoxx 600 & EUR Treasury 7-10y & Silver \\
Hang Seng (HK) & TIPS & Platinum \\
Emerging Markets & Corporate Bonds & Palladium \\
World & BUND & Nickel \\
Sector: Real Estate & & \\
Sector: Consumer & & \\
Sector: Health Care & & \\
Sector: Communications & & \\
Sector: Financials & & \\
Sector: Industrials & & \\
Sector: Semiconductors & & \\
Sector: Energy & & \\
\hline Note. SP $=$ Standard \& Poor's; US $=$ United States of America; TIPS = Treasury Inflation Protected Securities; EM = Emerging Markets.
\end{tabular}


than Model 1 but still with concern for stability, lowering the portfolio's volatility a little:

Set objective: Rate of return

To: Maximum

Additional constraints: $S R>=1$

\subsection{Model 5: maximize Sharpe ratio and return}

In this model, similar to the previous model (Model 4), the concern is to provide some extra returns to the investor, but still with concern for stability, lowering the portfolio's volatility a little:

Set objective: SR

To: Maximum

Additional constraints: Rate of return $>=10 \%$

\subsection{Model 6: maximize the minimal yearly return}

This model "guarantees" a minimum annual return. It can generate positive returns each year. Essentially, it maximizes the minimum:

Set objective: Minimum return of each year

To: Maximum

Table 2 below summarizes the main similarities and differences between the previous models presented in Navas et al. (2020) and the new ones. The differences occur in models 3 and 5. The other models are similar to those of Navas et al. (2020).

\section{Preliminary Data Analysis}

Data on market-adjusted prices were collected from the Yahoo Finance and Investing.com databases for all assets between 2000 and 2020. The monthly data on the assets inform the calculation of returns. Figure 1 shows the fluctuations in monthly return, illustrating the synchronized behavior of returns compared to prices (Figure 1). The correlation matrix and collinearity statistics are shown in Table 3 and descriptive statistics of monthly returns on the assets are shown in Table 4.

Clusters are obvious and volatility is present throughout the period. It is also noted that the spikes differ in time and between the assets themselves, which is anticipated according to the proposal in this report. In general, spikes are more evident in silver, especially in 2005, which means that this is an asset with more price fluctuations (volatility). Compared to the following figure (Figure 2), the coordinated behavior of returns compared to prices is evident. The spikes are a lot more noticeable. It also gives a good picture of the volatility clusters.

As shown, the US markets are highly correlated and collineated with the European market and all equity sectors, although there is no correlation with the Chinese

Table 2

Similarities and differences between the models

\begin{tabular}{|c|c|c|}
\hline & Navas et al.(2020) & Reviewed \\
\hline \multirow[t]{3}{*}{ Model 1} & Objective: SR & Objective: SR \\
\hline & To: Max & To: Max \\
\hline & Constraints: none & Constraints: none \\
\hline \multirow[t]{3}{*}{ Model 2} & Objective: Return & Objective: Return \\
\hline & To: Max & To: Max \\
\hline & Constraints: none & Constraints: none \\
\hline \multirow[t]{3}{*}{ Model 3} & Objective: Return & Objective: Var \\
\hline & To: Max & To: Min \\
\hline & Constraints: $i_{2000-2010}=i_{2011-2018} ; i_{n}>0,5 \%$ & Constraints: none \\
\hline \multirow[t]{3}{*}{ Model 4} & Objective: Return & Objective: Return \\
\hline & To: Max & To: Max \\
\hline & Constraints: $S R>=1$ & Constraints: $S R$ >= 1 \\
\hline \multirow[t]{3}{*}{ Model 5} & Objective: Return & Objective: SR \\
\hline & To: Max & To: Max \\
\hline & Constraints: $\mathrm{SR}_{2000-2010}>=1 ; \mathrm{SR}_{2011-2018}>=1$ & Constraints: Return $>=10 \%$ \\
\hline \multirow[t]{3}{*}{ Model 6} & Objective: Min Return & Objective: Min Return \\
\hline & To: $\operatorname{Max}$ & To: $\operatorname{Max}$ \\
\hline & Constraints: none & Constraints: none \\
\hline
\end{tabular}

Note SR = Sharpe Ratio; Max = Maximum; Min = Minimum; $i$ = return for the year; Var = variation . 


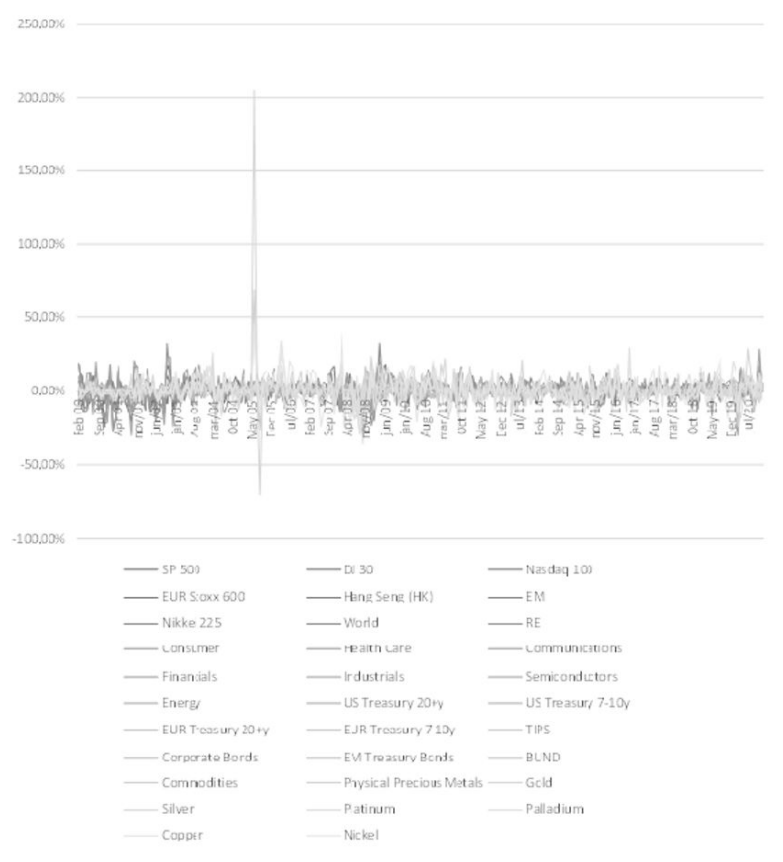

Figure 1. Monthly returns of the 32 assets Note. $\mathrm{SP}=$ Standard \& Poor's; US = United States of America; TIPS = Treasury Inflation Protected Securities; EM = Emerging Markets.

market, bonds, and commodities. With regards to bonds, there is a high inter-correlation and collinearity (except for emerging markets treasury bonds), and no correlation with commodities in general, or metals. Commodities, in general, are not correlated with each other, nor are metals. According to the literature, having uncorrelated assets is adequate and recommended to form a portfolio, because this provides real diversification and control of risk.

As seen in the table above, the standard deviation presents higher values than the mean, which means that volatility (uncertainty) is present for all forms of assets. In addition, the kurtosis has a value higher than 3 for real estate (equity), communications, financial services, long-term bonds, TIPs, corporate bonds, emerging market treasury bonds, physical precious metals, nickel, palladium, copper, and an exceptionally high value (higher than 73) for silver. This could imply that the distribution of monthly returns for these types of assets is non-normal. Silver is the most volatile asset, since it has the highest range (higher than 2.75) compared to other assets, as well as the highest skewness (higher than 7). This may mean that silver prices are more difficult to forecast.

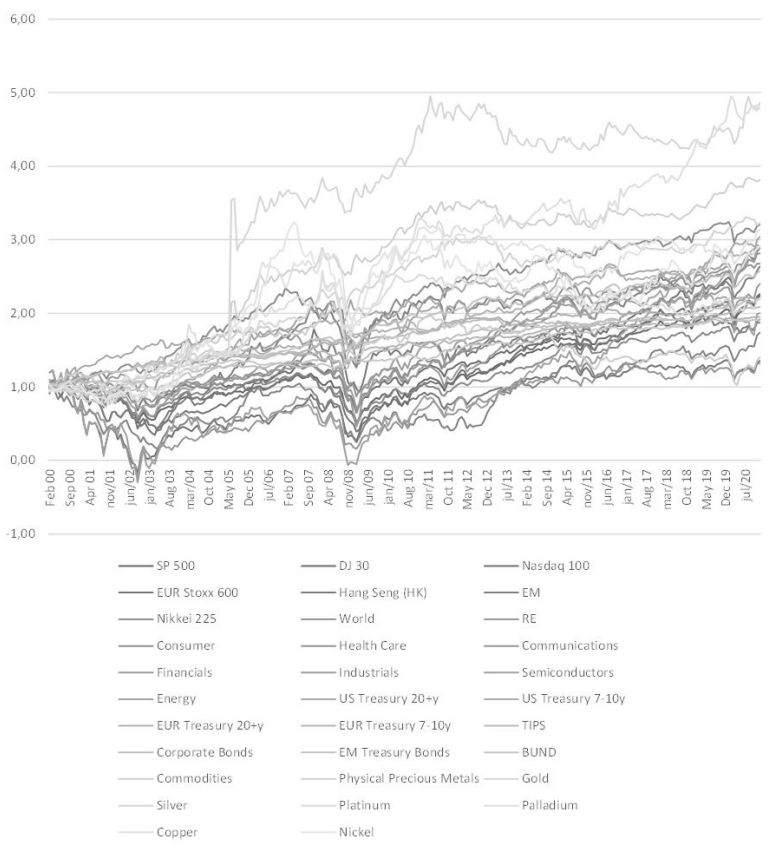

Figure 2. Accumulated returns of the 32 assets Notes. SP = Standard \& Poor's; US = United States of America; TIPS = Treasury Inflation Protected Securities; EM = Emerging Markets.

\section{Results}

\section{I GRG Nonlinear engine models}

This research uses GRG Nonlinear engines for linear solver problems. Table 5 displays the returns for each portfolio (Model 1 - Model 6) and Table 6 shows the assets for each portfolio.

Rate is the annual return of the portfolio and, as can be seen, the best result is $12.98 \%$ (full period, 20002020) for portfolio 2 , which is expected because we are maximizing the metric (rate), while it is less consistent because the Sharpe ratio provides the lowest value relative to the other portfolios. Here, we may conclude that prediction (2011-2020) fails because portfolio 2 is the most volatile one and if in the first decade (2000-2010) it shows 22\% yearly return (expected because we are maximizing it), in the second decade (2011-2020) this is only $3.79 \%$. This happens because of two reasons: (i) there is a negative correlation between volatility and predictions; and (ii) it is $100 \%$ composed of metals, which suffered a crash in 2013. Thus, to enhance predictions, the range of periods should include this period too in order to have three bear 


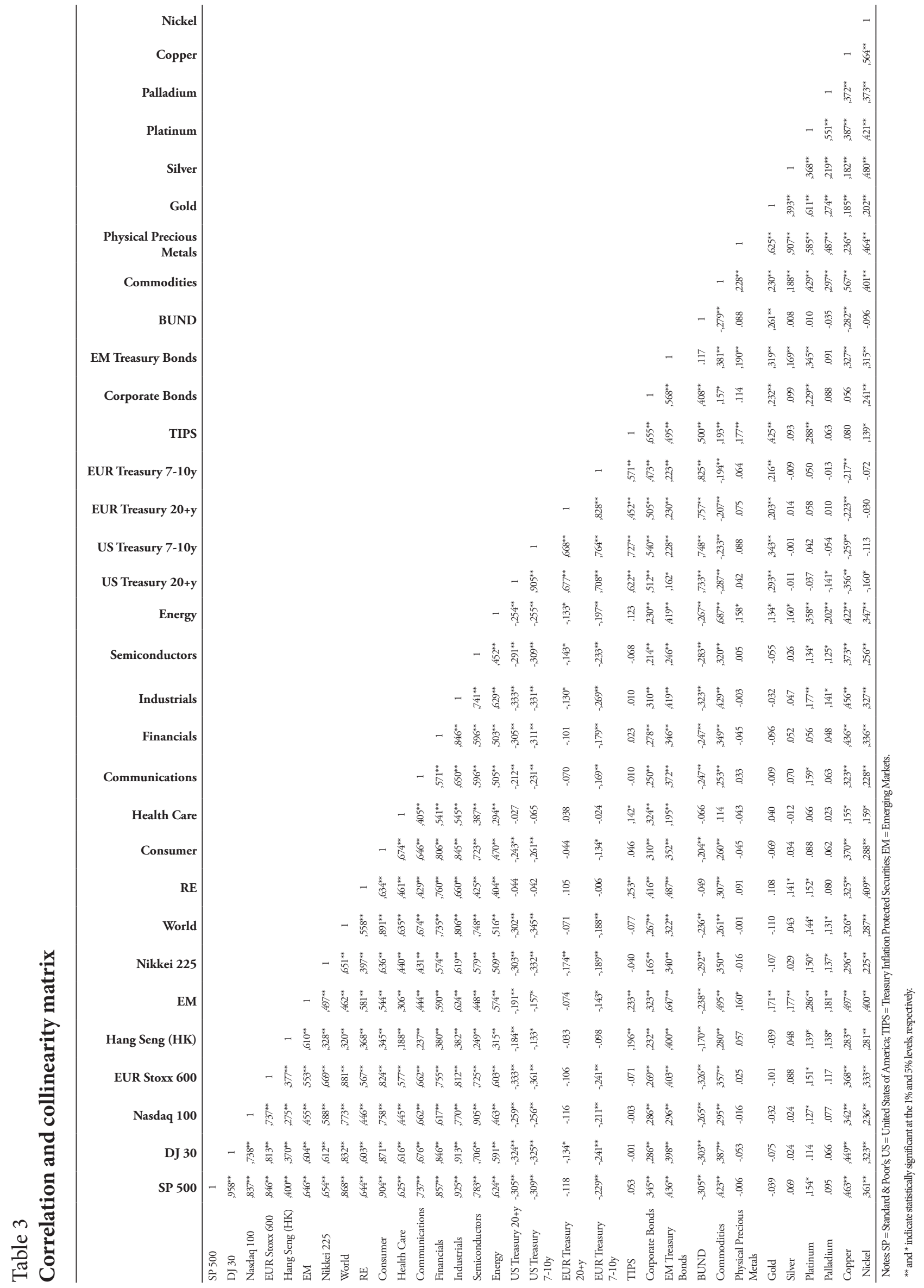


Table 4

Descriptive statistics of monthly returns of the 32 assets

\begin{tabular}{|c|c|c|c|c|c|c|c|c|c|c|c|}
\hline & Mean & $\begin{array}{l}\text { Standard } \\
\text { Error }\end{array}$ & Median & $\begin{array}{c}\text { Standard } \\
\text { Deviation }\end{array}$ & $\begin{array}{c}\text { Sample } \\
\text { Variance }\end{array}$ & Kurtosis & Skewness & Range & Minimum & Maximum & Sum \\
\hline SP 500 & 0.0003 & 0.0041 & 0.0071 & 0.0473 & 0.0022 & 0.6914 & -0.5352 & 0.2661 & -0.1694 & 0.0967 & 0.0451 \\
\hline DJ 30 & 0.0015 & 0.0040 & 0.0033 & 0.0454 & 0.0021 & 0.6579 & -0.4773 & 0.2467 & -0.1406 & 0.1060 & 0.1929 \\
\hline Nasdaq 100 & 0.0000 & 0.0073 & 0.0061 & 0.0837 & 0.0070 & 0.6263 & -0.3755 & 0.4593 & -0.2640 & 0.1952 & -0.0049 \\
\hline EUR Stoxx 600 & -0.0009 & 0.0042 & 0.0061 & 0.0482 & 0.0023 & 0.7268 & -0.5004 & 0.2761 & -0.1413 & 0.1347 & -0.1147 \\
\hline Hang Seng $(\mathrm{HK})$ & 0.0045 & 0.0058 & 0.0115 & 0.0661 & 0.0044 & 0.3295 & -0.1153 & 0.3841 & -0.1922 & 0.1919 & 0.5835 \\
\hline EM & 0.0090 & 0.0063 & 0.0117 & 0.0726 & 0.0053 & 0.3361 & -0.3060 & 0.4244 & -0.2558 & 0.1686 & 1.1727 \\
\hline Nikkei 225 & -0.0031 & 0.0052 & 0.0008 & 0.0594 & 0.0035 & 0.8577 & -0.5361 & 0.3668 & -0.2383 & 0.1285 & -0.4095 \\
\hline World & 0.0001 & 0.0039 & 0.0014 & 0.0448 & 0.0020 & 0.3141 & -0.1693 & 0.2331 & -0.1088 & 0.1242 & 0.0184 \\
\hline RE & 0.0097 & 0.0060 & 0.0171 & 0.0688 & 0.0047 & 6.6365 & -0.5928 & 0.6297 & -0.3044 & 0.3254 & 1.2760 \\
\hline Consumer & 0.0027 & 0.0045 & 0.0084 & 0.0510 & 0.0026 & 0.7649 & -0.2965 & 0.3142 & -0.1714 & 0.1428 & 0.3501 \\
\hline Health Care & 0.0024 & 0.0035 & 0.0029 & 0.0399 & 0.0016 & 1.0390 & -0.3985 & 0.2392 & -0.1425 & 0.0967 & 0.3133 \\
\hline Communications & -0.0023 & 0.0061 & 0.0000 & 0.0703 & 0.0049 & 3.5146 & 0.2636 & 0.5208 & -0.1972 & 0.3236 & -0.3078 \\
\hline Financials & 0.0018 & 0.0055 & 0.0046 & 0.0625 & 0.0039 & 3.0032 & -0.6740 & 0.4454 & -0.2276 & 0.2178 & 0.2328 \\
\hline Industrials & 0.0038 & 0.0052 & 0.0105 & 0.0590 & 0.0035 & 1.4494 & -0.3268 & 0.3942 & -0.1995 & 0.1946 & 0.4989 \\
\hline Semiconductors & -0.0018 & 0.0093 & 0.0019 & 0.1068 & 0.0114 & 0.0213 & -0.1841 & 0.5418 & -0.3035 & 0.2384 & -0.2356 \\
\hline Energy & 0.0080 & 0.0062 & 0.0111 & 0.0709 & 0.0050 & 0.5578 & -0.2602 & 0.4150 & -0.2076 & 0.2074 & 1.0464 \\
\hline US Treasury $20+y$ & 0.0080 & 0.0031 & 0.0112 & 0.0353 & 0.0012 & 3.4200 & -0.0193 & 0.2672 & -0.1249 & 0.1423 & 1.0458 \\
\hline US Treasury $7-10 y$ & 0.0057 & 0.0016 & 0.0074 & 0.0188 & 0.0004 & 1.8639 & 0.0153 & 0.1320 & -0.0547 & 0.0773 & 0.7417 \\
\hline $\begin{array}{l}\text { EUR Treasury } \\
20+y\end{array}$ & 0.0060 & 0.0024 & 0.0090 & 0.0275 & 0.0008 & 2.3171 & -0.2252 & 0.2063 & -0.0995 & 0.1068 & 0.7845 \\
\hline $\begin{array}{l}\text { EUR Treasury } \\
7-10 y\end{array}$ & 0.0042 & 0.0014 & 0.0056 & 0.0164 & 0.0003 & 1.0291 & -0.3042 & 0.1039 & -0.0547 & 0.0491 & 0.5541 \\
\hline TIPS & 0.0055 & 0.0017 & 0.0065 & 0.0193 & 0.0004 & 4.1104 & -0.7347 & 0.1461 & -0.0811 & 0.0650 & 0.7182 \\
\hline Corporate Bonds & 0.0044 & 0.0021 & 0.0045 & 0.0236 & 0.0006 & 9.5597 & 0.2851 & 0.2406 & -0.1072 & 0.1333 & 0.5742 \\
\hline $\begin{array}{l}\text { EM Treasury } \\
\text { Bonds }\end{array}$ & 0.0072 & 0.0034 & 0.0100 & 0.0388 & 0.0015 & 19.6210 & -2.1106 & 0.4338 & -0.2636 & 0.1702 & 0.9463 \\
\hline BUND & 0.0030 & 0.0013 & 0.0049 & 0.0149 & 0.0002 & -0.0486 & 0.2163 & 0.0745 & -0.0267 & 0.0478 & 0.3881 \\
\hline Commodities & 0.0068 & 0.0046 & 0.0078 & 0.0527 & 0.0028 & 2.0709 & -0.5580 & 0.3611 & -0.2233 & 0.1379 & 0.8846 \\
\hline $\begin{array}{l}\text { Physical Precious } \\
\text { Metals }\end{array}$ & 0.0181 & 0.0075 & 0.0185 & 0.0856 & 0.0073 & 30.4260 & 3.6434 & 0.9515 & -0.2542 & 0.6973 & 2.3696 \\
\hline Gold & 0.0136 & 0.0042 & 0.0181 & 0.0486 & 0.0024 & 1.3551 & -0.2263 & 0.3187 & -0.1801 & 0.1387 & 1.7762 \\
\hline Silver & 0.0272 & 0.0179 & 0.0055 & 0.2053 & 0.0421 & 73.8794 & 7.0660 & 2.7541 & -0.7067 & 2.0474 & 3.5590 \\
\hline Platinum & 0.0116 & 0.0051 & 0.0121 & 0.0584 & 0.0034 & 6.0441 & -0.6938 & 0.5094 & -0.2910 & 0.2184 & 1.5250 \\
\hline Palladium & 0.0175 & 0.0075 & 0.0199 & 0.0861 & 0.0074 & 4.0739 & 0.1952 & 0.6967 & -0.2955 & 0.4011 & 2.2883 \\
\hline Copper & 0.0165 & 0.0075 & 0.0148 & 0.0859 & 0.0074 & 3.0882 & -0.1068 & 0.7023 & -0.3615 & 0.3408 & 2.1562 \\
\hline Nickel & 0.0146 & 0.0085 & 0.0041 & 0.0976 & 0.0095 & 3.3822 & 0.4499 & 0.6928 & -0.2361 & 0.4567 & 1.9069 \\
\hline
\end{tabular}

Note. SP = Standard \& Poor's; US = United States of America; TIPS = Treasury Inflation Protected Securities; EM = Emerging Markets. 
Table 5

Results from the six models

\begin{tabular}{|c|c|c|c|c|c|c|}
\hline \multicolumn{7}{|c|}{ Panel A: Decade 2000-2010, GRG Nonlinear } \\
\hline & Model 1 & Model 2 & Model 3 & Model 4 & Model 5 & Model 6 \\
\hline & Max SR & Max return & Min var & Max return/SR & Max SR/Return & Max min \\
\hline 2000 & $6.99 \%$ & $-6.74 \%$ & $8.66 \%$ & $-6.37 \%$ & $9.52 \%$ & $8.50 \%$ \\
\hline 2001 & $5.81 \%$ & $-4.99 \%$ & $5.54 \%$ & $1.34 \%$ & $7.63 \%$ & $5.98 \%$ \\
\hline 2002 & $8.01 \%$ & $12.10 \%$ & $8.29 \%$ & $18.71 \%$ & $13.76 \%$ & $15.03 \%$ \\
\hline 2003 & $7.10 \%$ & $29.89 \%$ & $7.83 \%$ & $21.99 \%$ & $10.19 \%$ & $13.75 \%$ \\
\hline 2004 & $7.15 \%$ & $16.30 \%$ & $7.50 \%$ & $9.66 \%$ & $10.41 \%$ & $8.30 \%$ \\
\hline 2005 & $6.63 \%$ & $87.74 \%$ & $8.52 \%$ & $57.34 \%$ & $11.06 \%$ & $13.88 \%$ \\
\hline 2006 & $6.12 \%$ & $37.27 \%$ & $5.65 \%$ & $30.00 \%$ & $9.72 \%$ & $13.29 \%$ \\
\hline 2007 & $6.70 \%$ & $4.10 \%$ & $9.29 \%$ & $20.90 \%$ & $11.15 \%$ & $19.07 \%$ \\
\hline 2008 & $5.36 \%$ & $-37.39 \%$ & $5.31 \%$ & $-4.22 \%$ & $7.22 \%$ & $9.57 \%$ \\
\hline 2009 & $5.59 \%$ & $91.77 \%$ & $5.31 \%$ & $33.70 \%$ & $7.11 \%$ & $5.98 \%$ \\
\hline 2010 & $7.27 \%$ & $84.90 \%$ & $10.46 \%$ & $46.22 \%$ & $12.43 \%$ & $19.44 \%$ \\
\hline Rate & $6.61 \%$ & $22.03 \%$ & $7.47 \%$ & $19.32 \%$ & $10.00 \%$ & $11.98 \%$ \\
\hline SR & 8.56 & 0.54 & 4.39 & 1.00 & 4.96 & 2.64 \\
\hline \multicolumn{7}{|c|}{ Panel B: 2011-2020 } \\
\hline 2011 & $10.10 \%$ & $-6.58 \%$ & $14.55 \%$ & $19.54 \%$ & $16.86 \%$ & $25.83 \%$ \\
\hline 2012 & $9.80 \%$ & $6.38 \%$ & $8.45 \%$ & $4.11 \%$ & $10.45 \%$ & $4.60 \%$ \\
\hline 2013 & $-3.45 \%$ & $-19.61 \%$ & $-5.49 \%$ & $-32.01 \%$ & $-9.61 \%$ & $-16.43 \%$ \\
\hline 2014 & $16.51 \%$ & $0.12 \%$ & $15.47 \%$ & $6.58 \%$ & $23.17 \%$ & $17.38 \%$ \\
\hline 2015 & $0.84 \%$ & $-15.57 \%$ & $0.45 \%$ & $-3.68 \%$ & $0.05 \%$ & $-0.61 \%$ \\
\hline 2016 & $6.74 \%$ & $23.48 \%$ & $6.02 \%$ & $14.77 \%$ & $8.29 \%$ & $7.56 \%$ \\
\hline 2017 & $0.53 \%$ & $15.22 \%$ & $3.48 \%$ & $-2.07 \%$ & $2.82 \%$ & $5.25 \%$ \\
\hline 2018 & $0.54 \%$ & $-1.70 \%$ & $0.10 \%$ & $-0.60 \%$ & $0.92 \%$ & $-0.20 \%$ \\
\hline 2019 & $12.25 \%$ & $26.37 \%$ & $14.27 \%$ & $19.95 \%$ & $18.18 \%$ & $18.37 \%$ \\
\hline 2020 & $7.94 \%$ & $27.71 \%$ & $10.84 \%$ & $19.63 \%$ & $11.90 \%$ & $14.53 \%$ \\
\hline Rate & $5.86 \%$ & $3.79 \%$ & $6.44 \%$ & $2.43 \%$ & $7.64 \%$ & $6.52 \%$ \\
\hline SR & 0.98 & 0.23 & 0.95 & 0.16 & 0.81 & 0.57 \\
\hline \multicolumn{7}{|c|}{ Panel C: Full period 2000-2020 } \\
\hline Rate & $6.25 \%$ & $12.98 \%$ & $6.98 \%$ & $10.95 \%$ & $8.87 \%$ & $9.34 \%$ \\
\hline SR & 1.49 & 0.38 & 1.44 & 0.57 & 1.32 & 1.06 \\
\hline AVG & $6.41 \%$ & $17.66 \%$ & $7.17 \%$ & $13.12 \%$ & $9.20 \%$ & $9.96 \%$ \\
\hline MED & $6.74 \%$ & $12.10 \%$ & $7.83 \%$ & $14.77 \%$ & $10.19 \%$ & $9.57 \%$ \\
\hline MIN & $-3.45 \%$ & $-37.39 \%$ & $-5.49 \%$ & $-32.01 \%$ & $-9.61 \%$ & $-16.43 \%$ \\
\hline MAX & $16.51 \%$ & $91.77 \%$ & $15.47 \%$ & $57.34 \%$ & $23.17 \%$ & $25.83 \%$ \\
\hline$(+)$ & 20 & 14 & 20 & 15 & 20 & 18 \\
\hline$(-)$ & 1 & 7 & 1 & 6 & 1 & 3 \\
\hline
\end{tabular}

Note. SR = Sharpe Ratio; AVG = average annual returns; MED = median annual returns; MIN = minimum annual returns; MAX = maximum annual returns; (+) count of positive years; (-) count of negative years.

markets in equities (2000 and 2008), in bonds (2009 for US treasury bonds), and in commodities (2013 at least).

We are luckier in models 1,3 , and 5 and model 6 is not bad, because these models somehow minimize volatility and, as explained, this makes prediction easier. What regards to Model 1, it maximizes the Sharpe ratio and maintains a healthy Sharpe ratio in the second decade, very near to $1(0.98)$. With regards to earnings, they are around $6.41 \%$ a year. Note that this is a safety and not an aggressive portfolio. The first decade shows a yearly return superior to $6 \%(6.61 \%)$ and in the second decade it is near to $6 \%(5.86 \%)$. The worst year was 2013 , representing the only yearly loss $(-3.45 \%)$. The portfolio is composed of $87 \%$ bonds (essentially government bonds), $8 \%$ gold (crash in 2013), and only 4\% stocks (see Table 6).

Model 3 minimizes the yearly variation, so it reduces volatility too. In terms of results, it is similar to Model 1 but improved. In the second decade early returns 
are about $6.44 \%$ vs $5.86 \%$ (Model 1 ) and the Sharpe ratio is near to $1(0.95) .2013$ is the only year with a negative return, as happens in Model $1(-5.49 \%)$. With regards to the composition of this portfolio, $80 \%$ is bonds (vs $87 \%$ in Model 1 ), $12 \%$ is precious metals ( $7 \%$ gold vs $8 \%$ in Model 1), and 7\% is stocks (vs $4 \%$ in Model 1), as shown in Table 6.

Model 4 maximizes returns (primary) and the Sharpe ratio (secondary), but besides paying attention to the Sharpe ratio, the results are very similar to in Model
2. This model could not predict returns for the second decade (Sharpe ratio near to 0 ) and the reasons are the same as explained in the first paragraph regarding Model 2 (crash in metals in 2013). The yearly return is still positive $(2.43 \%)$ and if we ignore that negative year, we could earn $8.69 \%$ a year. Table 6 shows the composition of this portfolio and as we can see, as in Model 2, this portfolio is composed of $100 \%$ metals, with one difference: $70 \%$ is gold ( $0 \%$ in Model 2).

\section{Table 6}

\section{Constitution of the 6 models}

\begin{tabular}{|c|c|c|c|c|c|c|}
\hline & Model 1 & Model 2 & Model 3 & Model 4 & Model 5 & Model 6 \\
\hline & Max SR & Max return & Min var & Max return/SR & Max SR/Return & Max min \\
\hline \multicolumn{7}{|l|}{ SP 500} \\
\hline DJ 30 & & & & & & $2 \%$ \\
\hline Nasdaq 100 & & & $2 \%$ & & & \\
\hline \multicolumn{7}{|l|}{ EUR Stoxx 600} \\
\hline \multicolumn{7}{|l|}{ Hang Seng (HK) } \\
\hline \multicolumn{7}{|l|}{ EM } \\
\hline \multicolumn{7}{|l|}{ Nikkei 225} \\
\hline \multicolumn{7}{|l|}{ World } \\
\hline $\mathrm{RE}$ & & & & & $8 \%$ & \\
\hline \multicolumn{7}{|l|}{ Consumer } \\
\hline Health Care & & & $4 \%$ & & & $6 \%$ \\
\hline Communications & $4 \%$ & & $1 \%$ & & & \\
\hline \multicolumn{7}{|l|}{ Financials } \\
\hline Industrials & & & & & & $2 \%$ \\
\hline \multicolumn{7}{|l|}{ Semiconductors } \\
\hline Energy & & & & & & $2 \%$ \\
\hline US Treasury $20+y$ & & & $13 \%$ & & $18 \%$ & $38 \%$ \\
\hline $\begin{array}{l}\text { US Treasury } \\
7-10 y\end{array}$ & $7 \%$ & & $11 \%$ & & & \\
\hline $\begin{array}{l}\text { EUR Treasury } \\
20+y\end{array}$ & $20 \%$ & & $11 \%$ & & $33 \%$ & \\
\hline $\begin{array}{l}\text { EUR Treasury } \\
7-10 y\end{array}$ & $48 \%$ & & $10 \%$ & & $11 \%$ & \\
\hline TIPS & & & $9 \%$ & & & $1 \%$ \\
\hline Corporate Bonds & $4 \%$ & & $9 \%$ & & & \\
\hline $\begin{array}{l}\text { EM Treasury } \\
\text { Bonds }\end{array}$ & $8 \%$ & & $5 \%$ & & $7 \%$ & \\
\hline BUND & & & $11 \%$ & & & \\
\hline \multicolumn{7}{|l|}{ Commodities } \\
\hline $\begin{array}{l}\text { Physical Precious } \\
\text { Metals }\end{array}$ & & & $3 \%$ & & & \\
\hline Gold & $8 \%$ & & $7 \%$ & $70 \%$ & $20 \%$ & $44 \%$ \\
\hline Silver & & $43 \%$ & & $28 \%$ & & \\
\hline Platinum & & & $2 \%$ & & & \\
\hline Palladium & & $30 \%$ & & & & \\
\hline Copper & & $26 \%$ & & $3 \%$ & $2 \%$ & $2 \%$ \\
\hline Nickel & & & & & & \\
\hline
\end{tabular}


Model 5 is the inverse of Model 4: it maximizes the Sharpe ratio (primary) and returns (secondary). In terms of results, we can say that this is the best one, since it is the model which presents the highest return (7.64\% a year). Composition: $8 \%$ real estate, $70 \%$ treasury bonds (from a wide range of countries), and $22 \%$ metals (20\% gold).

Finally, Model 6 maximizes the minimum return of the first decade but because of the bad year for metals in 2013 , it suffers a loss of $-16.43 \%$ in that year. Metals had a prosperous decade between 2000-2010, which is why for this period the solver maximizes minimums, raising gold (44\%) and US long-term treasury bonds (38\%) in the portfolio's composition. Still, it predicts future returns well, providing the investor with more than $65 \%$ yearly returns in the second decade.

Conclusions are already made in the first paragraph, when we explain the results of Model 2. But to summarize: to enhance predictions, the range of periods that provide the sample for the solver should include prosperous and "extremely bad" periods for all kind of assets, in order to have three bear markets in equities (2000 and 2008), in bonds (2009 for US treasury bonds, when the stock market started to recover from the crash), and in commodities (2013 at least). And once again, volatility is negatively correlated to predictions and to returns, which is consistent with the literature.

Figure 3 below represents the accumulated returns of the six models, regarding the prediction period, which is the second decade (2010-2020). All models end with positive returns, especially Model 5, which surpasses double. Model 5 would duplicate the value invested in nine years. Also, all models would provide a positive return in the year of the pandemic.

As can be seen, the tendency is clear. Model 5 presents the highest positive tendency, following by Model 6 (close to double the investment), Model 3, and
Model 1. Models 2 and 4 are the most volatile but still generate a return.

As can be seen in Table 7, Model 1 correlates to Model 5, 3, and 6, respectively. Model 2 is correlated to Model 4, which is expected according to the previous analysis. Model 3 is correlated to Models 5 and 6, respectively, and weakly correlated to Model 4. Model 4 is weakly correlated to Models 5 and 6. And Model 5 is correlated to Model 6.

Because we concluded that there is a negative correlation between volatility and predicting (models with less variation/volatility showed better results), we decided to go further in our investigation and performed a linear regression involving current returns, future returns, and volatility (we use standard deviation for this purpose). That is, returns are the dependent variable and standard deviation is the independent variable. We compare two periods: the full period (2000-2020) and the prediction period (2011-2020). The results are shown and explained below in Table 8.

As we can see, first, the standard deviation is always statistically significant, but the signs invert in the prediction period, from positive to negative. The explanation

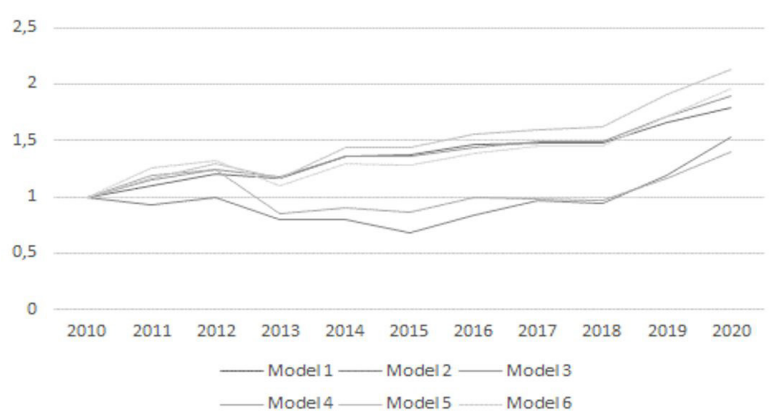

Figure 3. Portfolio performance: accumulated returns between 2010 and 2020 .

\section{Table 7}

\section{Correlation matrix of portfolios}

\begin{tabular}{ccccccc}
\hline & Model 1 & Model 2 & Model 3 & Model 4 & Model 5 & Model 6 \\
\hline Model 1 & 1 & & & & & \\
Model 2 & 0.17 & 1 & & & \\
Model 3 & 0.94 & 0.24 & 1 & 1 & 1 & \\
Model 4 & 0.43 & 0.85 & 0.53 & 0.55 & 0.89 \\
Model 5 & 0.97 & 0.24 & 0.97 & 0.69 & 1 \\
Model 6 & 0.77 & 0.31 & 0.91 & & \\
\hline
\end{tabular}


Table 8

\section{Linear regression: returns vs standard deviation}

\begin{tabular}{cccc}
\hline & Full period & \multicolumn{2}{c}{ Prediction } \\
\cline { 2 - 4 } Variable & $\mathbf{2 0 0 0 - 2 0 2 0}$ & $\mathbf{2 0 1 1 - 2 0 2 0}$ \\
\cline { 2 - 4 } & Coef. & $-0.337^{*}$ \\
\hline StdDev & $0.335^{* *}$ & -2.17 & Coef. \\
t-statistic & 2.57 & $0.091^{* * *}$ \\
Intercept & $0.054^{* *}$ & 5.08 \\
t-statistic & 2.68 & 6 \\
N\# obs. & 12 & 0.425 \\
Adjusted R & 0.337 & 2 \\
\hline
\end{tabular}

Note. StdDev $=$ Standard Deviation; N\# obs. = Number of observations. ${ }^{* \star},{ }^{* *}$, and ${ }^{\star}$ indicate statistically significant at the $1 \%, 5 \%$, and $10 \%$ levels, respectively.

for this phenomenon is actually very simple: for the full period, the standard deviation has a positive sign, i.e., an increase of one unit in StdDev raises prices by $33.5 \%$, and we know that the more aggressive the asset or investment is, the better the possible return for the investor. But those assets are more sensitive to fluctuations and news, so it is more difficult to predict future returns (negative coefficient in 2011-2020 predicted period). In general, stocks are more volatile and are considered to be a more aggressive investment than bonds (treasury/government), but they can generate better returns in the long term.

\subsection{Comparison with "classical" authors' portfolios}

In this subchapter, we compare the compositions and returns of some well-known investors, such as Benjamin Graham ( $50 \%$ equity / $50 \%$ treasury bonds), David Swensen [ $50 \%$ equity (divided into $30 \% / 15 \%$ / 5\%), $15 \%$ treasury bonds, $15 \%$ TIPS, 20\% real assets], Ray Dalio [30\% equity, $55 \%$ treasury bonds (divided into $40 \%$ / 15\%), 7.5\% gold, $7.5 \%$ commodities], the successful young Brazilian investor, Thiago Nigro [50\% equity (divided into 25\% / 25\%), $25 \%$ treasury bonds, $25 \%$ real assets], and the one we call "ours" i.e. our portfolio based in these authors/ investors aiming to grow and preserve capital (25\% equity, 25\% US treasury bonds, 25\% EUR treasury bonds, 25\% physical precious metals). Note: David Swensen and Thiago Nigro focus their investments on real estate too, so we are going to consider this point. Some authors use the S\&P 500 where we generalize it as equity, but we use the consumer sector to improve the results and stability in terms of returns and they are still highly correlated.
Table 9 shows the composition of the six portfolios based in the aforementioned authors and Table 10 shows the return on these portfolios. All models present excellent values in terms of returns and Sharpe ratio.

\section{Conclusions}

Our study shows that robust portfolios can be generated where the risk is minimized and the return is maximized. The theory used is that of Markowitz (1959), whose study focuses on the "efficient frontier of optimal investment," while recommending a diversified portfolio to minimize risk. For this reason, six portfolio models were proposed and formed by a solver, where the solving method chosen is the GRG Nonlinear engine for linear solver problems. Then we tested 10 years forward in order to check if returns remain somehow similar to the previous 10 years (period where the solver was used).

With regards to the forecasted period, the results show that the GRG Nonlinear engine is efficient, providing positive returns for all six models, especially for those that have low volatility. It is highly noticeable that the forecasting power is inversely correlated with volatility.

We designed models for conservative, moderate, and aggressive investors. For a cautious investor, portfolio 1 is the most ideal, followed by portfolios 3 and 5 . Portfolio 1 shows a solid Sharpe ratio with very low volatility but lower returns relative to portfolios 3, 5, and 6. Portfolio 5 presents high performance $(7.64 \%$ annually for the forecasted period).

We went further in our research and took advantage of the database to simulate portfolios according to "classical" investors found in the literature, such as Graham, David, Swensen, Ray, and Dalio, and the modern 
Table 9

Composition of the well-known investors' portfolios

\begin{tabular}{|c|c|c|c|c|c|c|}
\hline & $\begin{array}{c}\text { Benjamin } \\
\text { Graham }\end{array}$ & David Swensen & David Swensen & \multirow{2}{*}{ Ray Dalio } & \multirow{2}{*}{ Thiago Nigro } & \multirow{2}{*}{$\begin{array}{c}\text { Ours } \\
\begin{array}{r}\text { (growth and } \\
\text { preservation) }\end{array}\end{array}$} \\
\hline & $50 / 50$ & (by countries) & (by sectors) & & & \\
\hline SP 500 & & $30 \%$ & & & & \\
\hline \multicolumn{7}{|l|}{ DJ 30} \\
\hline \multicolumn{7}{|l|}{ Nasdaq 100} \\
\hline EUR Stoxx 600 & & $15 \%$ & & & & \\
\hline \multicolumn{7}{|l|}{ Hang Seng (HK) } \\
\hline EM & & $5 \%$ & & & & \\
\hline \multicolumn{7}{|l|}{ Nikkei 225} \\
\hline \multicolumn{7}{|l|}{ World } \\
\hline $\mathrm{RE}$ & & & $5 \%$ & & $25 \%$ & \\
\hline Consumer & $50 \%$ & & $30 \%$ & $30 \%$ & $25 \%$ & $25 \%$ \\
\hline Health Care & & & $15 \%$ & & & \\
\hline \multicolumn{7}{|l|}{ Communications } \\
\hline \multicolumn{7}{|l|}{ Financials } \\
\hline \multicolumn{7}{|l|}{ Industrials } \\
\hline \multicolumn{7}{|l|}{ Semiconductors } \\
\hline \multicolumn{7}{|l|}{ Energy } \\
\hline US Treasury $20+y$ & $50 \%$ & $15 \%$ & $15 \%$ & $40 \%$ & $25 \%$ & $25 \%$ \\
\hline \multicolumn{7}{|l|}{ US Treasury $7-10 y$} \\
\hline EUR Treasury $20+y$ & & & $15 \%$ & $15 \%$ & & $25 \%$ \\
\hline \multicolumn{7}{|l|}{ EUR Treasury 7-10y } \\
\hline TIPS & & $15 \%$ & & & & \\
\hline \multicolumn{7}{|l|}{ Corporate Bonds } \\
\hline Physical Precious Metals & & $20 \%$ & $20 \%$ & $7,5 \%$ & $25 \%$ & $25 \%$ \\
\hline Gold & & & & $7,5 \%$ & & \\
\hline \multicolumn{7}{|l|}{ Silver } \\
\hline \multicolumn{7}{|l|}{ Platinum } \\
\hline \multicolumn{7}{|l|}{ Palladium } \\
\hline \multicolumn{7}{|l|}{ Copper } \\
\hline Nickel & & & & & & \\
\hline
\end{tabular}

Table 10

Results from generalized models used by “classical" investors

\begin{tabular}{|c|c|c|c|c|c|c|}
\hline \multicolumn{7}{|c|}{ Panel A: Decade 2000-2010, GRG Nonlinear } \\
\hline & \multirow{2}{*}{$\begin{array}{c}\begin{array}{c}\text { Benjamin } \\
\text { Graham }\end{array} \\
50 / 50\end{array}$} & \multirow{2}{*}{$\begin{array}{c}\text { David Swensen } \\
\text { (by countries) }\end{array}$} & \multirow{2}{*}{$\begin{array}{c}\text { David Swensen } \\
\text { (by sectors) }\end{array}$} & \multirow{2}{*}{ Ray Dalio } & Thiago Nigro & \multirow{2}{*}{ Ours } \\
\hline & & & & & $\begin{array}{l}\text { (growth and } \\
\text { preservation) }\end{array}$ & \\
\hline 2000 & $9.29 \%$ & $1.42 \%$ & $5.23 \%$ & $8.92 \%$ & $5.35 \%$ & $5.74 \%$ \\
\hline 2001 & $9.08 \%$ & $-3.00 \%$ & $3.18 \%$ & $9.12 \%$ & $7.49 \%$ & $7.53 \%$ \\
\hline 2002 & $-3.06 \%$ & $-6.08 \%$ & $-1.69 \%$ & $4.74 \%$ & $3.63 \%$ & $6.05 \%$ \\
\hline 2003 & $16.37 \%$ & $17.11 \%$ & $18.99 \%$ & $13.38 \%$ & $22.74 \%$ & $14.12 \%$ \\
\hline
\end{tabular}

Note. $\mathrm{SR}=$ Sharpe ratio; ER = Excess return (compared to the benchmark); MEAN = Mean annual returns; MED = Median annual returns; MIN = Minimum annual returns; MAX = Maximum annually returns; (+) count of positive years; (-) count of negative years . Cells in grey represent the best result compared to other portfolios. 
Table 10

Continued...

\begin{tabular}{|c|c|c|c|c|c|c|}
\hline \multicolumn{7}{|c|}{ Panel A: Decade 2000-2010, GRG Nonlinear } \\
\hline & $\begin{array}{c}\text { Benjamin } \\
\text { Graham }\end{array}$ & David Swensen & David Swensen & \multirow{2}{*}{ Ray Dalio } & Thiago Nigro & \multirow{2}{*}{ Ours } \\
\hline & $50 / 50$ & (by countries) & (by sectors) & & $\begin{array}{l}\text { (growth and } \\
\text { preservation) }\end{array}$ & \\
\hline 2004 & $10.08 \%$ & $9.73 \%$ & $10.09 \%$ & $9.45 \%$ & $14.74 \%$ & $9.47 \%$ \\
\hline 2005 & $3.51 \%$ & $23.65 \%$ & $19.37 \%$ & $11.68 \%$ & $23.59 \%$ & $23.65 \%$ \\
\hline 2006 & $8.38 \%$ & $15.17 \%$ & $14.84 \%$ & $9.46 \%$ & $20.96 \%$ & $12.50 \%$ \\
\hline 2007 & $2.35 \%$ & $9.06 \%$ & $3.85 \%$ & $7.23 \%$ & $0.26 \%$ & $7.37 \%$ \\
\hline 2008 & $-5.60 \%$ & $-21.22 \%$ & $-12.96 \%$ & $1.55 \%$ & $-16.04 \%$ & $-2.48 \%$ \\
\hline 2009 & $2.61 \%$ & $20.53 \%$ & $18.56 \%$ & $3.86 \%$ & $21.55 \%$ & $11.17 \%$ \\
\hline 2010 & $15.85 \%$ & $19.59 \%$ & $21.44 \%$ & $17.08 \%$ & $28.58 \%$ & $21.88 \%$ \\
\hline Rate & $6.05 \%$ & $6.95 \%$ & $8.67 \%$ & $8.69 \%$ & $11.31 \%$ & $10.41 \%$ \\
\hline SR & 0.90 & 0.53 & 0.84 & 2.06 & 0.89 & 1.47 \\
\hline \multicolumn{7}{|c|}{ Panel B: 2011-2020 } \\
\hline 2011 & $17.95 \%$ & $5.70 \%$ & $11.31 \%$ & $18.94 \%$ & $11.88 \%$ & $14.39 \%$ \\
\hline 2012 & $11.50 \%$ & $9.78 \%$ & $13.11 \%$ & $10.25 \%$ & $11.58 \%$ & $11.07 \%$ \\
\hline 2013 & $7.99 \%$ & $0.66 \%$ & $5.11 \%$ & $-1.48 \%$ & $-3.17 \%$ & $-3.48 \%$ \\
\hline 2014 & $21.98 \%$ & $10.04 \%$ & $22.98 \%$ & $22.81 \%$ & $19.96 \%$ & $22.18 \%$ \\
\hline 2015 & $9.28 \%$ & $-1.64 \%$ & $6.65 \%$ & $4.92 \%$ & $2.69 \%$ & $2.61 \%$ \\
\hline 2016 & $4.81 \%$ & $7.70 \%$ & $7.03 \%$ & $6.89 \%$ & $8.46 \%$ & $9.28 \%$ \\
\hline 2017 & $8.38 \%$ & $10.71 \%$ & $5.26 \%$ & $5.67 \%$ & $7.04 \%$ & $4.11 \%$ \\
\hline 2018 & $-2.64 \%$ & $-4.31 \%$ & $0.80 \%$ & $-0.37 \%$ & $-1.04 \%$ & $1.08 \%$ \\
\hline 2019 & $20.61 \%$ & $22.95 \%$ & $24.33 \%$ & $20.79 \%$ & $24.55 \%$ & $22.87 \%$ \\
\hline 2020 & $22.88 \%$ & $13.67 \%$ & $16.40 \%$ & $20.16 \%$ & $14.28 \%$ & $19.16 \%$ \\
\hline Rate & $11.92 \%$ & $7.16 \%$ & $10.86 \%$ & $10.30 \%$ & $9.20 \%$ & $9.72 \%$ \\
\hline SR & 1.50 & 0.95 & 1.45 & 1.19 & 1.11 & 1.11 \\
\hline \multicolumn{7}{|c|}{ Panel C: Full period 2000-2020 } \\
\hline Rate & $8.80 \%$ & $7.05 \%$ & $9.71 \%$ & $9.45 \%$ & $10.30 \%$ & $10.08 \%$ \\
\hline SR & 1.11 & 0.65 & 1.07 & 1.39 & 0.95 & 1.27 \\
\hline MEAN & $9.12 \%$ & $7.68 \%$ & $10.18 \%$ & $9.76 \%$ & $10.91 \%$ & $10.49 \%$ \\
\hline MED & $9.08 \%$ & $9.73 \%$ & $10.09 \%$ & $9.12 \%$ & $11.58 \%$ & $9.47 \%$ \\
\hline MIN & $-5.60 \%$ & $-21.22 \%$ & $-12.96 \%$ & $-1.48 \%$ & $-16.04 \%$ & $-3.48 \%$ \\
\hline MAX & $22.88 \%$ & $23.65 \%$ & $24.33 \%$ & $22.81 \%$ & $28.58 \%$ & $23.65 \%$ \\
\hline$(+)$ & 18 & 16 & 19 & 19 & 18 & 19 \\
\hline$(-)$ & 3 & 5 & 2 & 2 & 3 & 2 \\
\hline
\end{tabular}

Note. $\mathrm{SR}=$ Sharpe ratio; $\mathrm{ER}=$ Excess return (compared to the benchmark); MEAN = Mean annual returns; MED = Median annual returns; MIN = Minimum annual returns; MAX = Maximum annually returns; $(+)$ count of positive years; (-) count of negative years. Cells in grey represent the best result compared to other portfolios.

investor Thiago Nigro, and we proposed a new one based on a uniform distribution. Simulating for a period of 21 years (2000 to 2020), the best return is for Thiago Nigro (10.30\% annually), but in terms of Sharpe ratio, Ray Dalio performs best with a value of 1.39 .

Our contribution is to provide a wider variety of portfolios that can be easily utilized by institutional and private investors, and considering that there are several ETFs or funds out there on the market today, it is straightforward for everybody to use as a single model. It was shown that it is feasible to design very efficient portfolios, increase returns, and cut back on risk. The results are implemented using the MPT from Markowitz (1959, 2010).

The limitation of the study is the fact that the data used to predict the composition of the portfolios did not take into consideration the crash of gold and precious metals in 2013. Optimal data should include years with 
normality in all assets (checked), excellent periods for all kinds of assets (checked), and bear markets/crashes for all kinds of assets (checked for equity and bonds, not checked for precious metals - a big factor in this study).

For future research, it would be interesting to add to the equity section some different systems of picking stocks instead of indices alone and then rerun the solver.

\section{Acknowledgements}

The views expressed in this paper are those of the authors and do not necessarily represent the views of the institutions with which they are affiliated. The authors acknowledge research and its financial support from the FCT (NECE: UID/GES/04630/2019). We thank the financial support given by FCT, I.P., the Portuguese national funding agency for science, research and technology, under the Project UIDB/04521/2020 and by BRU - Business Research Unit (IBS, Lisbon, Portugal) and by Instituto Politécnico de Lisboa as part of the IPL/2020/FIN/ISCAL projects.

\section{References}

ABOURA, S., \& WAGNER, N. (2016). Extreme asymmetric volatility: Stress and aggregate asset prices. Journal of International Financial Markets, Institutions \& Money, 41, 47-59.

ANG, A., HODRICK, R. J., XING, Y., \& ZHANG, $X$. (2006). The cross-section of volatility and expected returns. Journal of Finance, 61(1), 259-299.

ANG, A., HODRICK, R. J., XING, Y., \& ZHANG, $X$. (2009). High idiosyncratic volatility and low returns: International and further U.S. evidence. Journal of Financial Economics, 91(1), 1-23.

ASSAF, A. Neto. (2009). Extreme observations and risk assessment in the equity markets of MENA region: Tail measures and Value-at-Risk. International Review of Financial Analysis, 18(3), 109-116.

BENTES, S. M. (2011). Sobre a medição da volatilidade nos mercados bolsistas internacionais: Evidência dos países do G7. São Paulo: Colibri.

BENTES, S. R., MENEZES, R., \& FERREIRA, N. (2013). On the asymmetric behaviour of stock market volatility: Evidence from three countries. International Journal of Academic Research, 5(4), 24-32.
BRAILSFORD, T., \& FAFF, R. (1996). An evaluation of volatility forecasting techniques. Journal of Banking and Finance, 20(3), 419-438.

EASLEY, D., HVIDKJAER, S., \& O'HARA, M. (2002). Is information risk a determinant of asset returns? The journal of finance, 57(5), 2185-2221.

ENGLE, R. F. (1982). Autoregressive conditional heteroscedasticity with estimates of the variance of United Kingdom inflation. Econometrica, 50(4), 987-1007.

FAMA, E. F. (1970). Efficient capital markets: A review of theory and empirical work. Journal of Finance, 25(2), 383-417.

FAMA, E. F. (1998). Market efficiency, long-term returns, and behavioural finance. Journal of Financial Economics, 49(2), 283-306.

FELTHAM, G. A., \& OHLSON, J. A. (1995). Valuation and clean surplus accounting for operating and financial activities. Contemporary Accounting Research, 11(2), 689-731.

FELTHAM, G. A., \& OHLSON, J. A. (1999). Residual earnings valuation with risk and stochastic interest rates. The Accounting Review, 74(2), 165-183.

FRANCIS, J., LAFOND, R., OLSSON, P., \& SCHIPPER, K. (2005). The market pricing of accruals quality. Journal of accounting and economics, 39(2), 295-327.

GABRIEL, V. M. S. (2014). Multivariate models to forecast portfolio value at risk: From the dot-com crisis to the global financial crisis. Revista Brasileira de Gestão de Negócios, 16(51), 299-318.

GRAHAM, B. (2003). The intelligent investor: The definitive book on value investing. London: Paperback.

HIRSHLEIFER, D. (2015). Behavioral finance. Annual Review of Financial Economics 7, 133-159.

JESÚS-GUTIÉRREZ, R., \& SANTILLÁN-SALGADO, R. J. (2019). Conditional extreme values theory and tailrelated risk measures: Evidence from Latin American stock markets. International Journal of Economics and Financial Issues, 9(3), 127-141.

LAMBERT, R., LEUZ, C., \& VERRECCHIA, R. E. (2007). Accounting information, disclosure, and the cost of capital. Journal of accounting research, 45(2), 385-420.

LAMEIRA, V. J., NESS, W. L., Jr., QUELHAS, O. L., \& PEREIRA, R. G. (2013). Sustentabilidade, valor, 
desempenho e risco no mercado de capitais brasileiro. Revista Brasileira de Gestão de Negócios, 15(46), 76-90.

LUSARDI, A., \& MITCHELL, O. (2011). Financial literacy around the world: An overview. Journal of Pension Economics \& Finance, 10(4), 497-508.

MARIMOUTOU, V., RAGGAD, B., \& TRABELSI, A. (2009). Extreme value theory and value at risk: Application to oil market. Energy Economics, 31(4), 519-530.

MARKOWITZ, H. M. (1952). Portfolio selection. Journal of Finance, 7(1), 77-91.

MARKOWITZ, H. M. (1959). Portfolio selection: Efficient diversification of investments. New York: Wiley. Ness, Quelhas, Pereira

MARKOWITZ, H. M. (2010). Portfolio theory: As I still see it. Annual Review of Financial Economics, 2, 1-23.

MARTINS, V. G., MONTE, P. A., \& MACHADO, M. A. (2019). Analysis of risk and mispricing hypotheses of accruals: Evidence from Brazil. Revista Brasileira de Gestão de Negócios, 21(1), 169-186.

MIKOSZ, K. D., MACEDO, M. R., \& ROMA, C. M. (2020). Expected return, firm fundamentals, and aggregate systemic risk: An analysis for the Brazilian market using an accounting-based valuation model. Revista Brasileira de Gestão de Negócios, 22(2), 271-289.

MUTU, S., BALOGH, P., \& MOLDOVAN, D. (2011). The efficiency of value at risk models on central and Eastern European stock markets. International Journal of Mathematics and Computers in Simulation, 2(5), 110-117.

NAVAS, R. D., BENTES, S. R, \& GAMA, A. P. M. (2018). Is the European stock market asymmetric? Evidence from the Euronext 100 returns. Postgraduate Conference, Faro, Portugal, 9.

NAVAS, R. D., BENTES, S. R., \& NAVAS, H. V. (December 12th, 2020). Optimized portfolios: All seasons strategy. doi: 10.5772/intechopen.95122. Retrieved from: https://www.intechopen.com/books/quality-controlintelligent-manufacturing-robust-design-and-charts/ optimized-portfolios-all-seasons-strategy

ORLITZKY, M., SCHMIDT, F., \& RYNES, S. (2003). Corporate social and financial performance: a meta-analysis. Organization Studies, 24(3), 403-441.
PIOTROSKI, J. (2000). Value investing: The use of historical financial statement information to separate winners from losers. Journal of Accounting Research, 38, 1-41.

PIOTROSKI, J. (2005). Discussion of "separating winners from losers among low book-to-market stocks using financial statement analysis". Review of Accounting Studies, 10(2/3), 171-184.

PIOTROSKI, J., \& SO, E. C. (2012). Identifying expectation errors in value/glamour strategies: A fundamental analysis approach. Review of Financial Studies, 25(9), 2841-2875.

RICHARDSON, S., TUNA, I., \& WYSOCKI, P. (2010). Accounting anomalies and fundamental analysis: A review of recent research advances. Journal of Accounting \& Economics, 50, (2-3), 410-454.

ROBBINS, T. (2014). Money: Master the game. New York: Simon \& Schuster LTD.

SANVICENTE, A. Z., \& BELLATO, L. L. (2004). Determinação do grau necessário de diversificação de uma carteira de açóes no mercado de capitais brasileiro. Seminários em Administração - SEMEAD, SP, São Paulo, 7. Retrieved from https://repositorio.usp.br/item/001401678 SILVA, R. F., CARMONA, C. U., \& LAGIOIA, U. C. (2011). A Relação entre o risco e as práticas de governança corporativa diferenciada no mercado brasileiro de açóes: Uma abordagem sob a égide da teoria dos portfólios de Markowitz. Revista Brasileira de Gestão de Negócios, 13(39), 175-192.

SLOAN, R. (1996). Do stock prices fully reflect information in accruals and cash flows about future earnings? The Accounting Review, 71(3), 289-315.

SOROS, G. (2009). O Novo paradigma dos mercados financeiros. Coimbra: Ediçóes Almedina, SA.

TEIXEIRA, E. A., NOSSA, V., \& FUNCHAL, B. (2011). O índice de sustentabilidade empresarial (ISE) e os impactos no endividamento e na percepção de risco. Revista de Contabilidade \& Finanças, 22(55), 29-44.

WU, L., MENG, Q., \& VELAZQUEZ, J. (2015). The role of multivariate skew-Student density in the estimation of stock market crashes. The European Journal of Finance, 21(13-14),1144-1160.

ZHAO, X., SCARROTT, C., OXLEY, L., \& REALE, M. (2010). Extreme value modelling for forecasting market crisis impacts. Applied Financial Economics, 20(1-2), 63-72. 


\section{Financial support:}

Name of the funding agency/OR/ There are no funding agencies to report.

\section{Conflicts of interest:}

The authors have no conflict of interest to declare.

\section{Copyrights:}

RBGN owns the copyrights of this published content.

\section{Plagiarism analysis:}

RBGN performs plagiarism analysis on all its articles at the time of submission and after approval of the manuscript using the iThenticate tool.

\section{Authors:}

1. Raúl D. Navas, Instituto Politécnico de Lisboa - ISCAL, Lisboa, Portugal and NECE - Research Center in Business Sciences (NECE-UBI), Covilhã, Portugal

E-mail: rdnavas@iscal.ipl.pt

2. Sónia R. Bentes, Instituto Politécnico de Lisboa - ISCAL, Lisboa, Portugal, Business Research Unit - Instituto Universitário de Lisboa (BRU-IUL), Lisbon, Portugal

E-mail: smbentes@iscal.ipl.pt

\section{Authors' Contributions:}

$\mathbf{1}^{\text {st }}$ author: Definition of research problem; Development of hypotheses or research questions (empirical studies); Development of theoretical propositions (theoretical work); Definition of methodological procedures; Data Collection; Literature review; Statistical analysis; Analysis and interpretation of data; Critical revision of the manuscript; Manuscript writing.

$2^{\text {nd }}$ author: Definition of research problem; Development of hypotheses or research questions (empirical studies); Development of theoretical propositions (theoretical work); Definition of methodological procedures; Data Collection; Literature review; Statistical analysis; Analysis and interpretation of data; Critical revision of the manuscript; Manuscript writing. 